\title{
STORAGE TEMPERATURE INFLUENCES POSTHARVEST QUALITY OF WILD PLUM (XIMMENIA AMERICANA L.) FRUIT
}

\author{
V. E. Emongor ${ }^{*}$ And G. Ramagonono \\ (V. E. E. \& G. R.: Department of Crop and Soil Sciences, Botswana Uni- \\ versity of Agriculture and Natural Resources, Private Bag 0027, Gabo- \\ rone, Botswana, Tel: phone: +267-3650209, Fax:+267-3928753). \\ *Corresponding author'semail:vemongor@gmail.com orvemongor@buan.ac.bw.
}

\begin{abstract}
Wild plum has many medicinal, therapeutic and nutritive uses, but its fruits are collected in the wild and less researched. The aim of this study was to evaluate the effects of storage temperature on postharvest fruit quality of wild plum. The fruits of wild plum were subjected to different storage treatments at $0,5,10$ and $15 \pm 1{ }^{\circ} \mathrm{C}$ in a completely randomized design. The results showed that as storage temperature decreased below $15^{\circ} \mathrm{C}$, the incidence and severity of chilling injury significantly $(\mathrm{p}<0.05)$ increased. As storage temperature increased from 0 to $15^{\circ} \mathrm{C}$ fruit titratable acidity (TTA) and vitamin $\mathrm{C}$ content significantly $(\mathrm{p}<0.05)$ decreased, but juice $\mathrm{pH}$, soluble solids content (SSC) and weight loss significantly $(\mathrm{p}<0.05)$ increased. The decrease in TTA and vitamin C content, and increase in SSC and juice $\mathrm{pH}$ was attributed to fruit ripening. The increase in fruit weight loss was attributed to higher transpiration and respiration. It was concluded that to extend the storage-life and marketing period of wild plum fruits, the fruits should be stored at $15^{\circ} \mathrm{C}$ and $90-95 \% \mathrm{RH}$.
\end{abstract}

Keywords: Ximenia americana, Chilling injury and incidence, Vitamin C, Soluble solids content, Acidity

\section{Introduction}

Wild plum, scientifically known as Ximenia americana L., is a bush-forming shrub, named after a Spanish Priest Francisco Ximónez (Orwa et al., 2009). The genus Ximenia, is part of the Olacaceae family of plants that comprises of eight species (Orwa et al., 2009). Wild plum is widespread throughout the tropics in Africa, India and South East Asia, and also Australia, New Zealand, Pacific Islands, West Indies, Central and South America (Sarmento et al., 2015). The fruit tree is mostly solitary, distributed in open lands, savannahs, galley forests, along coastal areas, dry forests, semi-arid bushland and even in sandy woodlands (Feyssa et al., 2010).

Many wild plants have economic, medicinal and forage values in addition to preserving cultural heritages and maintaining ecological balance by providing various ecosystem services (Feyssa et al., 2012). Indigenous people have knowledge of the use and management of wild plum. Over harvesting and lack of proper management can lead to the extinction of a species (Feyssa et al., 2012). Bahru et al. (2010) reported detailed uses and 
management of wild plum in the semi-arid regions of Afar and Oroma of Ethiopia. Wild plum is broadly used in non-traditional medicine in regions where it is distributed (Le et al., 2012).

When ripe, the fruit is eaten as a dessert and can be used to make juice, jams, jellies, or an intoxicating alcoholic drink (Orwa et al., 2009; Feyssa et al., 2012). Wild plum has been reported to have medicinal properties, displayed by its antimicrobial, antifungal, anticancer, antioxidant, pesticidal and haematological effects (Feyssa et al. 2010). These properties are complimented by chemical compounds of wild plum fruit, seed, leaves and roots, which are phenolics, dietary fibres, minerals, vitamin $\mathrm{C}$ (antioxidants), saponins, glycosydes, flavonoids, carotenoids, tannins, alkaloids, quinones and terpenoids (Feyssa $e t$ al., 2010; 2012; Orwa et al., 2009). Wild plum fruit is reported to be rich in antioxidants such as vitamin $\mathrm{C}$, polyphenols, anthocyanins and carotenoids (Lamien-Meda et al., 2008; Silva et al., 2008; Sarmento et al., 2015).

There is an increasing global demand for traditional and rare fruits, which increases the gastronomic diversity as they provide new flavours, aromas, colours, and attractive appearance for consumers (Ortiz-Hernández \& Carrillo-Salazar, 2012). Fruit commercialization of wild plum is however, affected by drop in quality due to inappropriate postharvest handling, which largely determines the economic outcome of fruit marketing (Toivonen \& Hodges, 2011). Temperature is the most important environmental factor that influences the deterioration of harvested horticultural commodities. Most perishable commodities last longest at a temperature near $0^{\circ} \mathrm{C}$ (Emongor, 2010; Kader, 2013). However, most fruits that have originated in the tropical and subtropical regions are sensitive to cold temperatures, especially when exposed to low temperatures that are above the freezing point
(Gross et al., 2002). Such produce is injured when stored below their critical temperature, which generally ranges between 10 and $13^{\circ} \mathrm{C}$ for most varieties. Due to sensitivity of tropical fruits to chilling injury, transport of these fruits for most distant markets is generally only successful by air. No appropriate technology has been developed for storage of wild plum fruit (Feyssa et al., 2010). In Botswana and other parts of the world, wild plum is among the least exploited edible wild plant species, but highly consumed by local inhabitants in most settlements. Due to high perishability and unknown storage temperature requirement, marketing of wild plum is uncommon or virtually impossible. This research was undertaken to elucidate the optimum storage temperature for wild plum fruit.

\section{Fruit collection site}

\section{Experimental}

Wild plum fruits were collected from the outskirts of Molepolole village, in a settlement known as Seherelela, where the fruit trees were found in clusters or scattered on the hills and rocky soils of the area. The area has an altitude of $1,112 \mathrm{~m}$ above sea level with an average rainfall of $484 \mathrm{~mm}$ per annum. The rainfall pattern is comprised of the driest period in the month of July which records $3 \mathrm{~mm}$ of rainfall and the wettest month of January with a precipitation of $87 \mathrm{~mm}$ on average. The average annual temperature is $19.5^{\circ} \mathrm{C}$. The lowest temperature is recorded in July at an average of $12.2^{\circ} \mathrm{C}$, while January records the warmest temperature of $24.7^{\circ} \mathrm{C}$ on the average. Due to seasonality of wild plum fruits, the experiment was carried out from December 2016 to March 2017 when fruits were available in the forest.

\section{Experimental site and design}

The experiment was conducted in the Crop and Soil Sciences Department in the Crop Physiology Laboratory at The Botswana University of 
Agriculture and Natural Resources (BUAN) between December 2016 and March 2017. BUAN is located at Content Farm Sebele (Latitude $24^{\circ} 33^{\prime} \mathrm{S}$ and Longitude $25^{\circ} 54^{\prime} \mathrm{E}$; - altitude $994 \mathrm{~m}$ above sea level). The experimental design was a completely randomized design (CRD) replicated three times. The treatment was storage temperature at $0,5,10$ and $15 \pm$ $1{ }^{\circ} \mathrm{C}$. Fresh wild plum fruits were picked randomly at physiological maturity from different wild plum trees clustered in one area exposed to similar environmental conditions. At harvest, the fruit was firm, deep orange/yellow, uniform and free from bruises and defects judged subjectively based on epidermal colour. Fruits were washed to remove soils and other external material. Three hundred and forty fruits were harvested for the study and stored in various temperatures stated above. Four refrigerators were set at temperatures of $0,5,10$, and $15 \pm 1{ }^{\circ} \mathrm{C}$.

\section{Dependent variables determined}

The dependent variables determined were fruit development, fruit juice soluble solids content (SSC), total fruit titratable acidity (TTA), $\mathrm{pH}$, vitamin $\mathrm{C}$ content, chilling injury (CI) (incidence and severity) and storage life of the fruit in cold storage and after storage at room temperature. Fruit development was determined by measuring fruit diameter and length $(\mathrm{mm})$ of ten tagged fruits every week for 10 weeks using a veneer calliper, starting one week after full bloom.

\section{Titratable acidity}

The fruit titratable acidity was determined according to AOAC (1996). Ten fruit were cut and mixed. A composite sample of $100 \mathrm{~g}$ was weighed, then $100 \mathrm{ml}$ of distilled water was added. The sample was homogenized and filtered through 5-layers of cheese cloth. Then 20 $\mathrm{ml}$ of filtrate (juice) was put in a $50-\mathrm{ml}$ conical flask and two drops of $1 \%$ phenolphtha- lein indicator added. The samples were titrated with $0.1 \mathrm{~N} \mathrm{NaOH}$ to end point ( $\mathrm{pH} 8.2$ ). The results were expressed as total titratable acidity equivalents using the formula given below. Total titratable acidity $(\mathrm{g} / 100 \mathrm{ml}$ juice $)=(\mathrm{ml}$ base x normality base x 1x 100 x 2)/ml sample

\section{Soluble solids content}

The soluble solids content (SSC) was determined according to AOAC (1996) using a hand refractometer (Atago Model N1, American Optical, New York). Ten fruits per treatment were pinched using a scapel. Three drops of juice were directly placed on the prism surface of the refractometer and the average sugar content was determined in Brix but expressed as $\% \mathrm{SSC}$.

\section{Juice $p H$}

The extracted fruit juice was used to determine the $\mathrm{pH}$ using a $\mathrm{pH}$ meter. The $\mathrm{pH}$ meter was immersed into the juice after being calibrated using the buffer.

\section{Vitamin C (ascorbic acid) content}

Vitamin C content was determined using 2, 6-dichloroindophenol titrimetric method according to AOAC (1996). Ascorbic acid reduces oxidation-reduction indicator dye (2, 6-dichloroindophenol) to colourless solution. The fruit pulp was cut and mixed to form a composite sample. Then $100 \mathrm{~g}$ of the composite sample was weighed. Then $100 \mathrm{~g}$ of the composite sample was homogenized with 100 $\mathrm{ml}$ of metaphosphoric acid-acetic acid solution. The sample was filtered with five layers of cheese cloth. Then $20 \mathrm{ml}$ of the filtrate was pipetted into a $100 \mathrm{ml}$ conical flask and two drops of thymol blue $(0.04 \%)$ indicator added. The sample was titrated with 2, 6-dichloroindophenol solution to end point. Also three sample aliquots containing the standard ascorbic acid solution $(20 \mathrm{ml})$ with metaphosphoric acid-acetic acid solution (for correction or 
blank) was titrated with 2, 6-dichloroindophenol. Calculation of vitamin $\mathrm{C}$ content was done according to AOAC (1996) following the formula given below and expressed as $\mathrm{mg} / \mathrm{g}$ :

$$
\text { mg ascorbic acid/g }=(\mathrm{X}-\mathrm{B}) *\left(\frac{\mathrm{F}}{\mathrm{E}}\right) *\left(\frac{\mathrm{V}}{\mathrm{Y}}\right),
$$

where $\mathrm{X}=$ average $\mathrm{ml}$ for sample titration, $\mathrm{B}=$ averege $\mathrm{ml}$ for blank titration, $\mathrm{F}=$ $\mathrm{ml}$ of standard ascorbic acid soulution, $\mathrm{E}=$ weight of sample ground, $\mathrm{V}=$ volume of initial sample solution and $\mathrm{Y}=$ volume of aliquot titrated.

\section{Chilling injury (incidence and severity)}

Chilling injury was evaluated daily for incidence and severity in storage according to the method of Zhao et al. (2006). Chilling injury (CI) incidence was assessed from all stored fruits per treatment. Fruit showing symptoms of CI were counted and expressed as a percentage. Chilling injury severity was evaluated on a predetermined scale of 0-3: 0 being no injury; 1 being slight injury (where $1 / 3$ of the fruit showed some injury symptoms); 2 moderate injuries (where $2 / 3$ of the fruit showed some injury symptoms) and 3 being severe injury (determined by more than $67 \%$ of the fruit showing injury depending on the peel damage).

Chilling injury index was calculated by the following equation;

CII $($ score $0-3)=\sum_{i=0}^{N}(C I \times n) \div N$

Where $\mathrm{CI}=$ Chilling injury level; $\mathrm{n}=$ Number of fruit at the CI level; and $\mathrm{N}=$ Total number of fruit in the treatment.

\section{Shelf-life}

Shelf-life was determined by the number of days' fruits maintained their fresh physiological status at different temperatures until they become unacceptable due to development of physiological disorders.

\section{Data analysis}

The data collected was subjected to analysis of variance (ANOVA) using the Statistical Anal- ysis System (SAS). Treatment means were separated using the Least Significant Difference (LSD) at $\mathrm{p} \leq 0.05$.

\section{Fruit development}

\section{Results and discussion}

The results of the study showed that wild plum fruit significantly $(\mathrm{p} \leq 0.05)$ increased both in length $(2.64 \mathrm{~cm})$ and diameter $(2.14 \mathrm{~cm})$ with increase in time reaching a maximum size at nine weeks after full bloom (Fig. 1). Fruit growth and development followed a simple sigmoid growth curve (Fig. 1). Fruits can display simple, double or triple sigmoid growth curves depending on the fruit species (Jackson et al., 2011; Emongor \& Tautsagae, 2016). The increase in fruit size was attributed to cell division in the first four weeks after full bloom and then followed by cell elongation and expansion (Jackson et al., 2011). The size of fruit growth greatly depends on the cultivar and early maturing cultivars with a short period of fruit growth are generally smaller than fruit of later maturing cultivars of the same species that have a longer period for growth (Jackson et al., 2011). The fruit size of wild plum is relatively small $(2.7-3 \mathrm{~cm}$ long, $1.5-2.5 \mathrm{~cm}$ in diameter) due to the short fruit growth period of 8-9 weeks after full bloom, which is genetically pre-determined (Maundu et al., 1999; Orwa et al., 2009). 


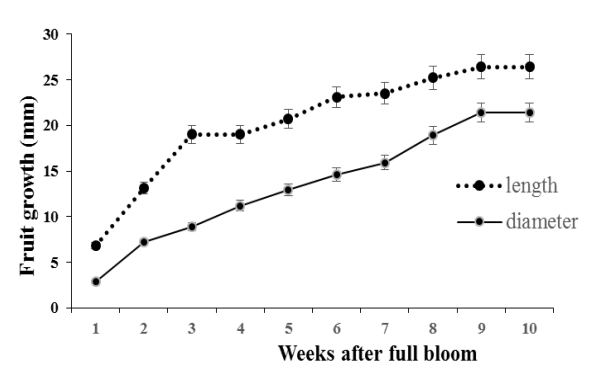

Fig. 1: Fruit growth pattern of wild plum; Error bar: Mean \pm standard error.

\section{Chilling injury incidence and severity}

The results of the study showed that storage temperature significantly $(\mathrm{p} \leq 0.05)$ influenced CI incidence and severity of wild plum fruits (Fig. 2, 3). As storage temperature decreased below $15^{\circ} \mathrm{C}$, the incidence and severity of chilling significantly $(\mathrm{p} \leq 0.05)$ increased (Fig. 2,3 ). Chilling injury symptoms observed were shrivelling, dark scald discoloration, pitting, sunken lesions and poor colour development on wild plum fruits stored at storage temperatures of 0,5 , and $10^{\circ} \mathrm{C}$, though the incidence and severity varied with the storage temperature (Fig. 2, 3). Fruit stored at $\leq 10^{\circ} \mathrm{C}$ developed CI after 24 hours of storage (Fig. 2). After 2 days of storage at 0 and $5^{\circ} \mathrm{C}$, the CI severity had an index greater than 2 , implying the fruit was unmarketable. Fruit stored at $10^{\circ} \mathrm{C}$ attained CI injury severity index higher than 2 after 7 days of storage (Fig. 3). Wild plum fruit stored at $15^{\circ} \mathrm{C}$ did not develop chilling injury and had a storage-life of 28 days, respectively, (Figure 2, 4). Similar results have been reported concerning other tropical and subtropical fruits (Wang, 1993; Gross et al., 2002; Emongor, 2015; Emongor \& Tautsagae, 2016; Senewa, 2016). Several events have been suggested to be the primary cause of chilling injury, including a phase transition in membrane lipids, an alteration in the substrate specificity of a regulatory enzyme, a change in the cyto- skeletal structure, or an increase in cytosolic calcium which are genetically controlled (Han et al., 2006; Aghdam et al., 2012).

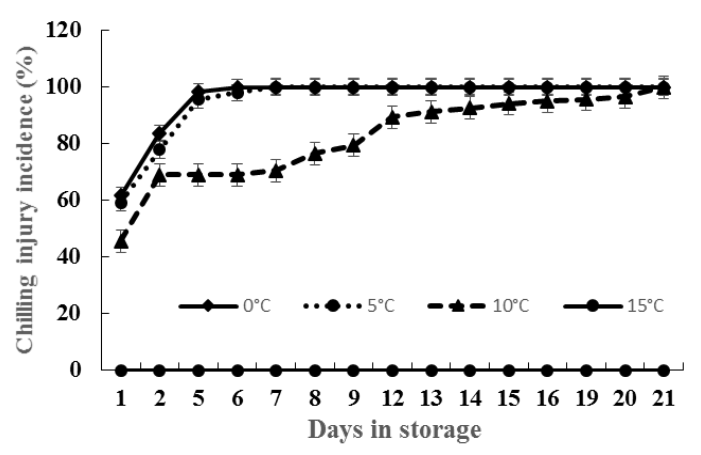

Fig. 2: Effect of storage temperature on chilling injury incidence; Error bar: Mean \pm standard error

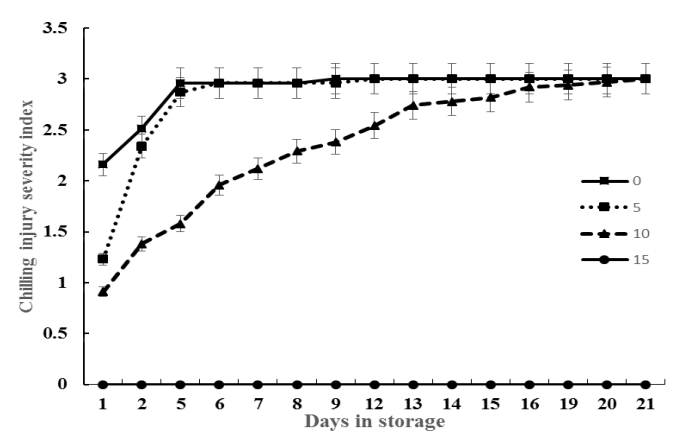

Fig. 3: Effect of storage temperature on chilling injury severity of wild plum; Error bar: Mean \pm standard error

\section{Storage-life}

Storage temperature significantly $(\mathrm{p} \leq 0.05)$ influenced wild plum fruit shelf-life (Fig. 4). Wild plum fruit stored at $15^{\circ} \mathrm{C}$ had significantly $(\mathrm{p} \leq 0.05)$ higher storage-life of 28 days than fruit stored at 0,5 or $10^{\circ} \mathrm{C}$ which had a storage-life of $1.5,2$ and 7 days, respectively (Fig. 4). Fruit stored at 0 and $5^{\circ} \mathrm{C}$ suffered severe $\mathrm{CI}$ after 2 days of storage making them 
unmarketable (Fig. 2, 3, 4). Temperature is the most important environmental factor that influences the deterioration of harvested horticultural commodities, most perishable commodities last longest at temperature near $0^{\circ} \mathrm{C}$, if not chilling sensitive (Emongor, 2010; Kader, 2013). However, most tropical and subtropical fruits are chilling sensitive when exposed to low temperatures that are above the freezing point (Gross et al., 2002; Emongor, 2015; Emongor \& Tautsagae, 2016; Senewa, 2016). Such crops, including wild plum, are injured when stored below the critical temperature between $10-13^{\circ} \mathrm{C}$ for most varieties. The results of the current study showed that in order to extend the postharvest life of wild plum fruits for about 28 days, the fruits should be stored at $15^{\circ} \mathrm{C}$ to avoid $\mathrm{CI}$.

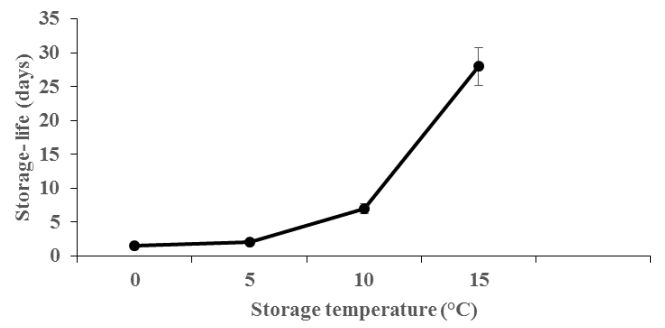

Fig. 4: Effect of storage temperature on shelf life of wild plum; Error bar: Mean \pm standard error.

\section{Titratable acidity and juice $\mathrm{pH}$}

Storage temperature significantly $(\mathrm{p} \leq 0.05)$ influenced wild plum fruit TTA (Fig. 5) and juice $\mathrm{pH}$ (Fig. 6). As storage temperature increased from 0 to $15^{\circ} \mathrm{C}$, fruit TTA and juice $\mathrm{pH}$ significantly ( $\mathrm{p} \leq 0.05)$ decreased (Fig. 5) and increased (Fig. 6), respectively. The response of wild plum fruit TTA to increasing storage temperature was a linear decrease with a correlation coefficient of 0.99 . At harvest, the fruit juice $\mathrm{pH}$ was 2.31 , however, after 28 days of storage, fruit juice $\mathrm{pH}$ ranged between 2.54 to 2.8 (Fig. 6). The flavour of fruits depends on the interaction of sugars, organic acids, phenolics, tannins and aroma volatiles (Prasanna et al., 2007; Paliyath \& Murr, 2008; Emongor, 2010; Seymour et al., 2013). In general, the concentration of acids decline during ripening, but the total number of acids increase (Paliyath \& Murr, 2008; Emongor; 2010; Seymour et al., 2013; Emongor, 2015). The decrease and increase in wild plum fruit TTA and juice $\mathrm{pH}$, respectively, with increasing storage temperature in the current study was attributed to increased level of fruit ripening. Immature fruits contain more acids that may decline during maturation and ripening due to gluconeogenesis (Prasanna et al., 2007; Paliyath \& Murr, 2008; Emongor, 2010; Seymour et al., 2013). Sarmento et al. (2015) reported that the TTA of wild plum ranged between 75.4 (immature fruit) to 65.3 (mature fruit) $\mathrm{mg} / 100 \mathrm{~g}$, while the juice $\mathrm{pH}$ ranged between 3.03 (immature fruit) to 2.96 (mature fruit). Silva et al. (2008) in Brazil reported that the juice $\mathrm{pH}$ of ripe wild plum fruit was 2.6. In the current study, at harvest, the wild plum fruit TTA and $\mathrm{pH}$ was $67 \mathrm{mg} / 100 \mathrm{ml}$ juice and 3.0, respectively, but after 28 days of storage, the fruit juice TTA and $\mathrm{pH}$ ranged between $35-55 \mathrm{mg} / 100 \mathrm{ml}$ and 2.54-2.8, respectively. The results of the current study and those of Silva et al. (2008), and Sarmento et al. (2015) showed that wild plum juice is acidic, which is a desirable characteristic for the processing industry as acidity contributes to an enhanced flavour and promotes a high dilution factor in the formulation of juices leading to a greater yield while low acidity dismisses any acidification during processing (Chakraverty et al., 2003). 


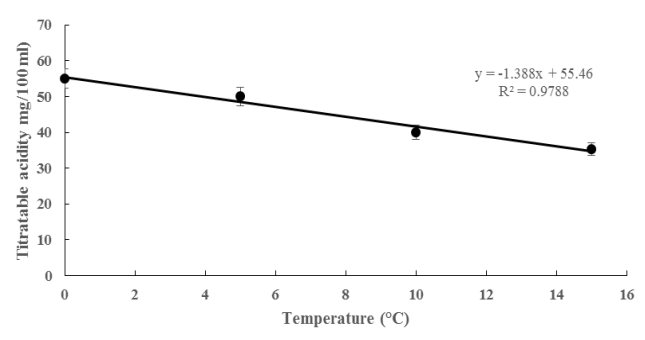

Fig. 5: Effect of storage temperature on titratable acidity 28 days after storage; Error bar: Mean \pm standard error

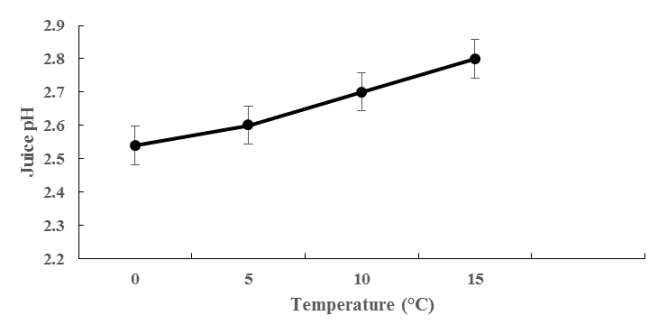

Fig. 6: Effect of storage temperature on juice $\mathrm{pH}$ at the end of storage; Error bar: Mean \pm standard error.

\section{Soluble solids content}

The result of the study showed that storage temperature significantly $(\mathrm{p} \leq 0.05)$ influenced fruit soluble solids content (SSC) 28 days after storage (Fig. 7). Fruit stored for 28 days at $0,5,10$ and $15^{\circ} \mathrm{C}$ had fruit SSC of 20.2, 23.6, 25.7 and 26.8\%, respectively (Fig. 7). The increase in fruit SSC of wild plum with increase in storage temperature was attributed to fruit ripening which promoted glucogenesis and hydrolysis of polysachharides especially starch (Aivalakis \& Katinakis, 2008; Paliyath $\&$ Murr, 2008). The relatively low SSC on wild plum fruit stored at low temperatures of 0,5 or $10^{\circ} \mathrm{C}$ was attributed to CI. Chilling injury negatively affects fruit ripening and caus- es uneven ripening (Emongor, 2015; Emongor $\&$ Tautsagae, 2016). From the results of the current study, the lowest safe temperature for long term exposure of mature wild plum fruits is $15^{\circ} \mathrm{C}$. Lowering the temperature further could inhibit ripening due to chilling injury hence abbreviated storage life (Kader, 2013).

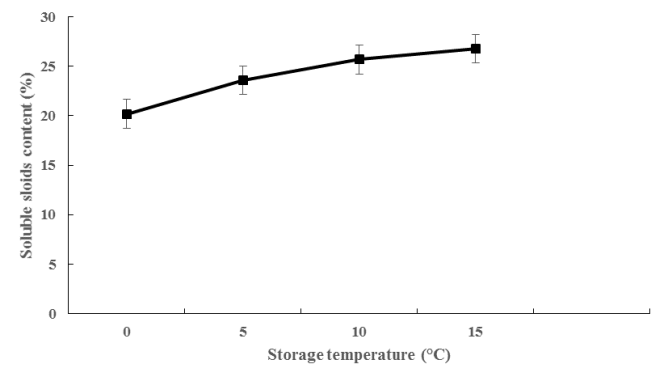

Fig. 7: Effect of storage temperature on fruit soluble solids content 28 days after storage; Error bar \pm standard error.

\section{Vitamin $C$}

Storage temperature had a significant ( $\mathrm{p} \leq$ 0.05) influence on the vitamin $\mathrm{C}$ content of wild plum 28 days after storage (Fig. 8). As storage temperature increased from 0 to $15^{\circ} \mathrm{C}$, fruit vitamin $\mathrm{C}$ content significantly $(\mathrm{p} \leq 0.05)$ decreased (Fig. 8). In the current study, the fruit vitamin C content at harvest was $76 \mathrm{mg} / 100 \mathrm{~g}$. However, after 28 days of storage at $0,5,10$ and $15^{\circ} \mathrm{C}$, fruit vitamin $\mathrm{C}$ content decreased from 76 to $8 \mathrm{mg} / 100 \mathrm{~g}$ (Fig. 8). Wild plum fruit has been reported in the semi-arid regions of Brazil to contain vitamin $\mathrm{C}$ of $170 \mathrm{mg} / 100 \mathrm{~g}$ (immature fruit) and 188-251 mg/100 g (mature fruit) (Silva et al., 2008; Sarmento et al., 2015). The difference in vitamin $C$ content of the current study and that of Silva et al. (2008) and Sarmento et al. (2015) might be due to climatic differences between Botswana and Brazil, stage of fruit maturity at harvest, and the species of wild plum (Kays \& Paull, 2004). 
Loss of vitamin $\mathrm{C}$ content in fruits and vegetables during storage at various temperatures is reported in literature (Kays \& Paull, 2004; Emongor, 2010; Emongor \& Tautsagae, 2016; Senewa, 2016). In the current study TTA and juice $\mathrm{pH}$ decreased and increased (loss of acidity), respectively, with increase in storage temperature which correlated with loss of vitamin $\mathrm{C}$, explaining the loss of vitamin $\mathrm{C}$. The loss of vitamin $\mathrm{C}$ is $\mathrm{pH}$ dependent, being slow in acid $\mathrm{pH}$, rapid at neutral $\mathrm{pH}$ and extremely rapid at alkaline pH (Kays \& Paull, 2004; Paliyath \& Murr, 2008; Emongor, 2010).

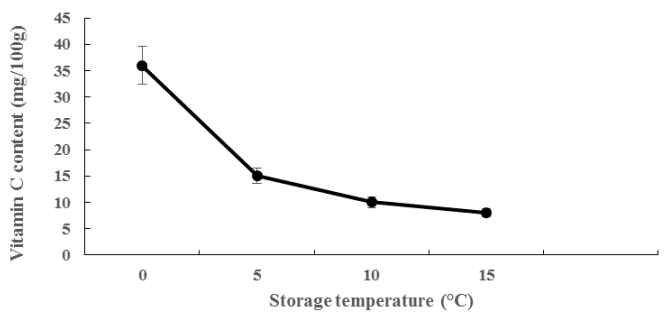

Fig. 8: Effect of storage temperature on fruit vitamin C content after 28 days of storage; Error bar: Mean \pm standard error.

\section{Weight loss}

Storage temperature significantly $(\mathrm{p} \leq 0.05)$ influenced wild plum fruit weight loss in storage (Fig. 9). As storage temperature increased, fruit weight loss significantly $(\mathrm{p} \leq 0.05)$ increased (Fig. 9). Fruit stored at $0^{\circ} \mathrm{C}$ had significantly (p $\leq 0.05$ ) lower fruit weight loss than fruit stored at 5,10 or $15^{\circ} \mathrm{C}$ (Fig. 9). In general, the higher the temperature the shorter the storage life of horticultural products and the greater the amount of loss within a given time, as most factors that destroy the produce or lower its quality occur at a faster rate as the temperature increases (Ball, 1997; Emongor, 2010). This applies to the rate of growth of spoilage microorganisms, the rate of indigenous physio- logical change, and physical processes such as water loss and wilting (Emongor, 2010). In the current study, as storage temperature increased from 0 to $15{ }^{\circ} \mathrm{C}$, wild plum fruit weight loss increased from $1.02 \%$ to $26.75 \%$, respectively, after 28 days of storage. The higher fresh weight loss of wild plum fruit at 5, 10, and 15 ${ }^{\circ} \mathrm{C}$ than at $0{ }^{\circ} \mathrm{C}$ was attributed to higher fruit transpiration and respiration rates at the higher temperatures (Ball, 1997; Kays \& Paull, 2004). Senewa (2016) reported that as mango fruit storage temperature increased from 4 to $25{ }^{\circ} \mathrm{C}$ fruit weight loss increased from 10.6 to $15.9 \%$. Similar results of fruit weight loss with increase in storage temperature have been reported in different fruits such as tangerine (Roongruangsri et al., 2013), squash (Wang, 1993), tomato (Žnidarčič, 2010), and avocado (Perez et al., 2004).

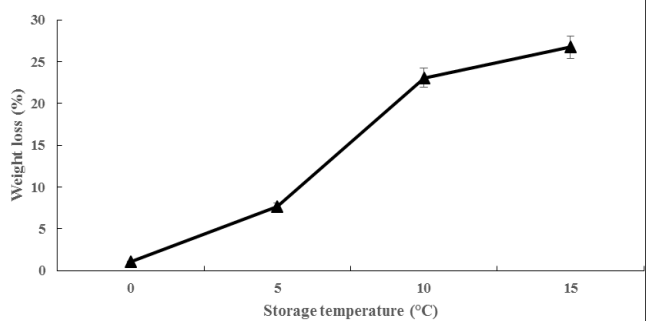

Fig. 9: Effect of storage temperature on weight loss of wild plum fruits 28 days after storage; bars are standard error.

\section{Conclusion}

Postharvest temperature management of wild plum fruits is important for their successful storage, extension of storage-life and marketing. This study showed that storage of wild plum fruits in temperatures below $15^{\circ} \mathrm{C}$ led to the development of CI. It is concluded that in order to extend the storage-life and marketing period (28 days) of wild plum fruits, the fruits should be stored at $15^{\circ} \mathrm{C}$ and $90-95 \% \mathrm{RH}$. It is 
recommended that this study on storage temperature of wild plum be repeated using other varieties and temperatures in the range of 10 to $15^{\circ} \mathrm{C}$.

\section{References}

Aghdam, M. S., Asghari, M. R. \& Moradbeygi, H. (2012) Effects of postharvest salicyclic acid treatment on reducing chilling injury in tomato. Romanian Biotechnological Letters 17 (2), $7466-7474$.

Aivalakis, G. \& Katinakis, P. (2008) Biochemistry and molecular physiology of tomato and pepper fruit ripening. The European Journal of Plant Science and Biotechnology 2 (1), 145 $-155$.

AoAC (1996) Association of Official Analytical Chemists Official Methods of Analysis. $17^{\text {th }}$ Edition, Arlington, Virginia, USA.

Bahru, T., Asfaw, Z. \& Sebsebe, D. (2010) Variation of indigenous botanical knowledge versus social characteristics between the afar and oromo nations in and around the semi-arid Awash National Park. Ethiopian Journal of Agricultural Science and Technology 2 (1), 1 - 13.

BALL, J. A. (1997) Evaluation of lipid-based edible coatings for their ability to preserve postharvest quality of green bell peppers. Master of Science Thesis, Virginia Polytechnic Institute and State University, Blacksburg, 89pp.।

Chakraverty, A., Mujumdar, A. S., Raghavan, G. S. V. \& Ramaswamy H.s. (2003) Handbook of postharvest technology: Cereals, Fruits, Vegetables, Tea, and Spices. Marcel Dekker Inc. Publication, New York, Basel, 884pp.

EMOngor, V. E. (2010) Postharvest physiology and technology Manual, Botswana College of Agriculture Printing Press, Gaborone, 256pp.

EMONGoR, V. E. (2015) The effects of temperature on storage life of mango. American Journal of Experimental Agriculture 5 (3), 252 - 261.

Emongor, V. E. \& Tautsagae, A. (2016) Effect of storage temperature on postharvest quality, ripening and marketability of marula fruits (Sclerocarya birrea subsp. caffra). British Journal of Applied Science and Technology 14 (5), $1-12$.

Feyssa, D. H., Nuoka, J. T., Asfaw, Z. \& Nyangito, M. M. (2010) Seasonal Ethiopia availability and consumption of wild edible plants in semi-arid Ethiopia: Implications to food security and climate change adaptation. Journal of Horticulture and Forestry 3, $138-149$.

Feyssa, D. H., Nuoka, J. T., Asfaw, Z. \& Nyangito, M. M. (2012) Uses and management of Ximenia americana. Olacaceae in semi-arid east Shewa, Ethiopia. Pakistan Journal of Botany 44 (4), $1177-1184$.

Gross, K. C., Wang, C. Y. \& Salveit, M. (2002) The commercial storage of fruits, vegetables and florist and nursery crops. http://www.ba.ars. usda.gov/hb66/index.html.

Han, J., Tian, S. P., Meng, X. H. \& Ding, Z. S. (2006) Response of physiologic metabolism and cell structures in mango fruits to exogenous methyl salicylate under low-temperature stress. Physiological Plantarum 128, 125 - 133.

Jackson, D. J., Looney, N. E. \& Morley-Bunk, M. (2011) Temperate and Subtropical Fruit Production. Third Edition, CABI International, 326pp.

James, D. B., Owolabi, A. O., Ibiyeye, H. \& Magaj, J. (2008) Assessment of the hepatic effects, heamatological effect and some phytochemical constituents of Ximenia americana L. (leaves, stem and root) extracts. African Journal of Biotechnology 7 (23), 4274 - 4278.

Kader, A. A. (2013) Postharvest technology of horticultural crops. An overview from Farm to Fork $\mathbf{1}, 1-8$.

Kays, S. J. \& Paull, R. E. (2004) Postharvest Biology. Exon Press, USA. 568p.

Lamien-Meda, M., Lamien, C. E., Compaore, M. M. Y. \& Roland, M. N. T. (2008) Polyphenol content and antioxidant activity of fourteen 
wild edible fruits from Burkina Faso. Molecules 13 (3), 581 - 594.

Le, N. H. T., Malteruda, K. E., Diallob, D. \& Paulsen, B. S. (2012) Bioactive polyphenols in Ximenia americana and the traditional use among Malian healers. Journal of Ethnopharmacology 139 (3), $858-862$.

Maundu, P. M., Ngugi, G. W. \& Kabuye, C. H. S. (1999) Traditional food plants of Kenya. Kenya Resources Centre for Indigenous Knowledge, National Museums of Kenya, Nairobi, 288pp.

Ortiz-Hernández, Y. D. \& Carrillo-Salazar, J. A. (2012) Pitahaya (Hylocereus spp.): a short review. Comunicata Scientiae 3 (4), 220 - 237.

Orwa, C., Mutua, A., Kindt, R. \& Jamnadass, R. H. (2009) Agroforestry Database: a tree reference and selection guide version 4.0. World Agroforestry Centre, Kenya http://www.feedipedia. org

Paliyath, G. \& Murr, D. P. (2008) Biochemistry of fruits. In: Postharvest Biology and Technology of Fruits, Vegetables, and Flowers. In: Paliyath, G., Murr, D. P., Handa, A. K., et al., (eds), Wiley-Blackwell, Publication, 19 $50 \mathrm{pp}$.

Perez, K., Mercado, J. \& Soto-Valdez, H. (2004) Effect of Storage Temperature on the Shelf Life of Hass Avocado (Persea americana). Food Science and Technology International 10 (2), $73-77$.

Prasanna, V., Prabha, T. N \& Tharanathan, R. N. (2007) Fruit ripening phenomena: An Overview. Critical Reviews in Food Science and Nutrition 47, 1 - 19.

RoONgruangsRi, W., Rattanapanone, N. \& LeKSAWASDI, N. (2013) Influence of storage condition on physio-chemical and biochemical of two tangerine cultivars. Journal of Agricultural Science 5, $70-84$.
Sarmento, J. D. A., Danta De Morais, P. L., Israel De Souza, F. Alcântara De Miranda, M. R. (2015) Physical-chemical characteristics and antioxidant potential of seed and pulp of $\mathrm{Xi}$ menia americana $\mathrm{L}$. from the semiarid region of Brazil. African Journal of Biotechnology 14 (20), $1743-1752$.

Senewa, B. P. (2016) Effects of temperature and hot water treatment duration on chilling injury and quality of mango (Mangifera indica L.). Master of Science Thesis, Crop Science and Production Department, Botswana University of Agriculture and Natural Resources, pp. 101.

Seymour, G. B., Ostergard, L. \& Chapman, N. H. (2013) Fruit development and ripening. Annual Review of Plant Biology 64, 219 - 241.

Silva, G.g., Souza, P.A., Morais, P., Santos, E.c., Moura, R. D. \& Menezes, J. B. (2008) Caracterizaçăo do fruto de ameixa Silvestre (Ximenia americana L.). Review of Brasilian Fruits 30 (2), $311-314$.

Toivonen, P. M. A. \& Hodges, D. M. (2011) Abiotic stress in harvested fruits and vegetables. In: Shanker, A. (ed.). Abiotic stress in plants Mechanisms and Adaptations. Techology China $39-58$.

Wang, C.Y. (1993) Approaches to reduce chilling injury of fruits and vegetables. Horticultural Reviews 15, 63 - 95.

Zhao, Z., Jiang, W., CaO, J. \& Gu, Y. (2006) Effect of cold-shock treatment on chilling injury in mango (Mangifera indica L. cv 'Wacheng') fruit. Journal of the Science of Food and Agriculture 86, $2458-2462$.

Žnidarĉiĉ, D., Ban, D., Oplanić, M., Karic, L. \& PozrL, T. (2010) Influence of postharvest temperatures on physicochemical quality of tomatoes (Lycopersicon esculentum Mill.). Journal of Food, Agriculture and Environment 18 (1), $21-25$. 